\title{
THE PROBLEM OF THE CAPE BEE (APIS MELLIFERA CAPENSIS ESCHOLTZ) : PARTHENOGENESIS - SIZE OF POPULATION - EVOLUTION
}

\author{
Friedrich RUTTNER \\ Institut für Bienenkunde Universität Frankfurt 637 Oberursel / Ts B.D.R.
}

\section{SUMMARY}

1. The classical type of $A$. $m$. capensis is characterized by a large spermatheca and an augmentation of the number of ovarioles in the workers as well as by the capacity of worker bees to reproduce by thelytokous parthenogenesis. No reliable external characteristics exist so far to determine this type (the dark colour of the abdomen and an increase in number of bristles on the wing being of relative value only). The area of distribution of the classical capensis, being restricted to the Cape Peninsula and its surroundings, is much smaller than indicated previously.

2. There is at present no geographical isolation, but an ecological adaptation to the specific climatic conditions of the Cape exists.

3. By several successive parthenogenetic generations a uniform capensis type was obtained from evidently heterozygous bees by permanent autoselection, the capensis workers starting earlier with oviposition.

4. Thelytokous reproduction of the capensis may be of selective advantage, as queenless colonies succeed to raise fertile queens from worker produced female larvae.

5. The classical capensis type is in danger of being lost due to the small size of the population (estimated No. - 20000 colonies) and to the migratory activity of beekeepers. The creation of a capensis sancturary on the Cape Peninsula is suggested.

\section{1. - INTRODUCTION}

In 1976 an APIMONDIA symposium on African Bees was held at Pretoria. An important topic at this meeting was the Cape bee, a unique race among all the others due to its biological pecularities. A post symposium tour along the southcoast of Africa was organized to provide an actual field experience in 
the biology of this bee and the ecological conditions in its area of distribution. The data and information which was collected there, together with the results of new experiments, allow for an attempt to analize the conditions of the evolution of this race as well of its present existence.

The Cape bee is different from all other races of bees as diploid female bees emerge from unfertilized eggs laid by worker bees. As to the development of reproductive organs (number of ovarioles, presence of complete spermatheca, fig. 1) the workers of the Cape bee are more like a queen than the workers of other races. The laying worker of capensis may even be called a pseudoqueen, as a court is formed around her and as she acquired the capacity to produce queen substance (9-oxo-decenoic acid) as do true queens (Ruttner, Koeniger and Veith 1976).

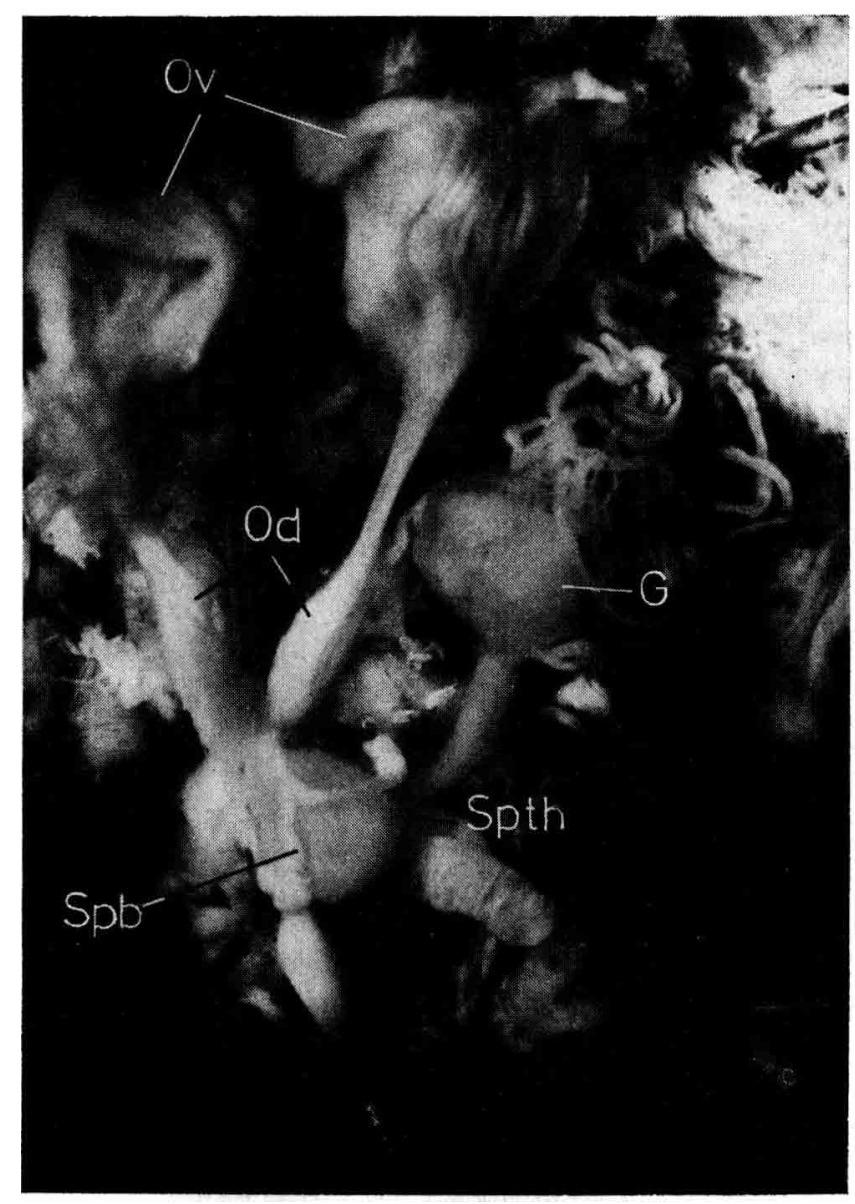

FIc. 1. - Reproductive organs of an egg laying capensis worker.

Ov $=$ ovary; Spth = spermatheca with gland ( $\mathrm{Sph})$.

$\mathrm{G}=$ poison sac; $\mathrm{Od}=$ oviduct. 
The material providing the base for the hitherto existing descriptions of the Cape bee (Onions 1912, Anderson 1963) originated exclusively from Cape Town and its surroundings (Stellenbosch). Thus the question arises : what is the size of the population of this peculiar bee? How large is the area of distribution?

\section{2. - biometrical characterization OF A. M. CAPENSIS}

As a prerequisite to finding an answer to these questions a clear definition has to be given for the type “ capensis ». This should be done preferably through characteristics of the exterior. In general capensis is designated as “ dark » in contrast to the " yellow » bee of Central Africa.

Obviously using only this criterion, Kerr and P. Araujo (1958) and GuY (1976) published a distribution map of A.m. capensis (fig. 2), showing a rather exact conformity with the so-called Winter Rainfall Area of South Africa.

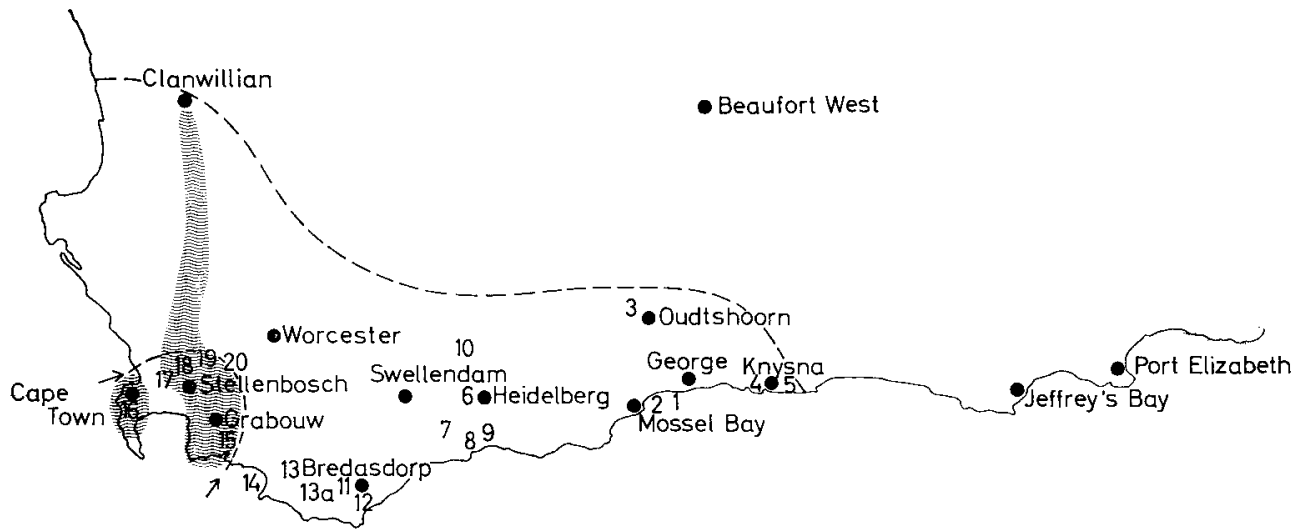

FIG. 2. - Origin of the samples investigated ( $\mathrm{N}^{*}$ 1-21) in the Cape Province.

Hatched field : humid zone of the Winter Rainfall Area

Dotted line : distribution limit of capensis as assumed so far (Kern and P. Araujo 1958, Guy 1976). Dotted line between arrows : limit of the "classical" capensis type.

However, pigmentation alone is not sufficient to characterize a race of bees. At least a number of additional external morphological marks should exist, but so far none were found to clearly discriminate between capensis and the bees of Central and Eastern Africa (DuPraw 1965, Ruttner 1976). It was impossible to determine this type using the known external measurements. Recently Woyke (1976) suggested that a higher density of bristles on the forewing could be used as a characteristic of the Cape bee. 
With our own samples this observation was confirmed to a limited degree only (tabl. 1). In the Cape bee a tendency of augmentation of the bristle number is perceptible, but this was verified statistically only in part. The overall sample of all bees from Transvaal and that of Stellenbosch are separated very well $(p<0,001)$, but not the differences between some of the individual colonies, e.g. No. 614 versus No. 569 or versus No. 718 .

TABLE 1. - Number of bristles on an area of $0,4 \mathrm{~mm}^{2}$ on the discoidal cell of the fore wing.

\begin{tabular}{|c|c|c|c|c|}
\hline Sample No. & Origin & & & number of bristles \\
\hline & & $\mathrm{n}$ & $\overline{\mathbf{x}}$ & $\mathrm{s}$ \\
\hline 613 & Transvaal & 20 & 80,30 & 9,54 \\
\hline 614 & $»$ & 20 & 82,10 & $8,07\{\bar{x}=81,37, \quad s=8,24$ \\
\hline 615 & " & 20 & 81,70 & $7,27 !$ \\
\hline 567 & Stellenbosch & 20 & 88,55 & 10,03 \\
\hline 569 & » & 20 & 85,30 & $8,50 /$ \\
\hline 571 & $»$ & 20 & 92,85 & $9,95 i^{x=87,60, \quad s=9,96}$ \\
\hline 718 & 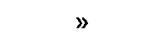 & 20 & 84,30 & $9,97:$ \\
\hline
\end{tabular}

Thus a significant characterization of the Cape bee using only external measurements was not yet found; but AnDenson (1976) reported a clear decrease in the number of ovarioles from the south to the north (tabl. 2). Parallel to the number of ovarioles a decrease in the size of the spermatheca was observed.

\begin{tabular}{|c|c|}
\hline Origin & $\begin{array}{c}\text { Mean number } \\
\text { of ovarioles }\end{array}$ \\
\hline tellenbosch & 19 \\
\hline Prince Albert & 14 \\
\hline Koekenaap & 8 \\
\hline Victoria West & 4 \\
\hline
\end{tabular}

From present knowledge it appears that for an exact diagnosis of the Cape bee only the way of reproduction and the development of reproductive organs of workers bees can be used :

1. Thelitokous parthenogenesis

2. Frequency and size of the spermatheca in worker bees

3. Average number of ovarioles in the worker ovary 
Nothing is known however in this respect about the bees in the assumed capensis region, except the data of Anderson, mentioned above.

\section{3. - SIZE AND DISTRIBUTION OF THE AUTOCHTHONOUS CAPENSIS POPULATION}

Sixteen samples of bees were collected during the official Congress tour and during a stay at Honey Wood Farm (near Heidelberg) and at Stellenbosch (fig. 2). Samples 17 to 21 were collected from capensis colonies, originating in Stellenbosch and kept at the Institut für Bienenkunde Oberursel, West Germany, for experimental purposes. It was determined by experiments that the worker bees from these 5 colonies reproduce by thelytokous parthenogenesis. This of course was not tested with the other samples; but data was obtained on the size of spermathecae and number of ovarioles (table 3 ).

TABLE 3. - Development of spermatheca and ovary of worker bees of colonies from the southern Cape region.

\begin{tabular}{|c|c|c|c|c|c|c|c|c|}
\hline & \multirow[t]{2}{*}{ No Origin } & \multirow[t]{2}{*}{ n } & \multicolumn{4}{|c|}{ Measurable spermathecae } & \multicolumn{2}{|c|}{$\begin{array}{c}\text { Number } \\
\text { of ovarioles }\end{array}$} \\
\hline & & & total & $\begin{array}{l}\text { " cape size " } \\
(>0,30 \mathrm{~mm})\end{array}$ & $\overline{\mathbf{x}}$ & $\max$ & $\overline{\mathbf{x}}$ & $\max$. \\
\hline 1 & Mosselbay I & 25 & 16,0 & 8,0 & 0,312 & 0,466 & 7,4 & 9 \\
\hline 2 & Mosselbay 2 & 17 & 0 & 0 & 一 & - & 6,0 & 8 \\
\hline 3 & Outshorn & 23 & 26,1 & 4,4 & 0,216 & 0,319 & 10,1 & 13 \\
\hline 4 & Knysna 1 & 16 & 12,5 & 0 & 0,129 & 0,172 & 6,6 & 11 \\
\hline 5 & Knysna 2 & 20 & 100 & 10,0 & 0,168 & 0,490 & 10,9 & 16 \\
\hline 6 & Heidelberg & 10 & 90 & 10,0 & 0,218 & 0,411 & 7,7 & 14 \\
\hline 7 & Malgas & 20 & 40,0 & 0 & 0,147 & 0,294 & 10,7 & 20 \\
\hline 8 & Witsand 1 & 20 & 5,0 & 5,0 & 0,539 & 0,539 & 12,5 & 15 \\
\hline 9 & Witsand 2 & 5 & 20,0 & 0 & 0,294 & 0,294 & 9,8 & 14 \\
\hline 10 & Honey Wood (Heidelberg) & 9 & 55,6 & 0 & 0,123 & 0,171 & 8,20 & 13 \\
\hline 11 & Bredasdorp 1 & 20 & 85,0 & 40,0 & 0,294 & 0,588 & 9,38 & 14 \\
\hline 12 & Bredasaorp 2 & 20 & 45,0 & 10,0 & 0,207 & 0,392 & 8,33 & 13 \\
\hline 13 & Fairfield & 20 & 40,0 & 5,0 & 0,162 & 0,392 & I 1,11 & 20 \\
\hline $13 \mathbf{a}$ & Elim & 20 & 25,0 & 5,0 & 0,157 & 0,319 & 11,39 & 20 \\
\hline 14. & Gans Bay & 20 & 5,0 & 0 & 0,147 & 0,147 & & \\
\hline 15 & Grabouw 1 & 20 & 15,0 & 15,0 & 0,327 & 0,343 & 14,33 & 19 \\
\hline $15 a$ & Grabouw 2 & 20 & 90,0 & 85,00 & 0,527 & 0,735 & 11,00 & 16 \\
\hline 16 & Cape Town & 21 & 80,95 & 66,7 & 0,476 & 0,686 & 17,18 & 26 \\
\hline 17 & Stellenbosch 1973/1 & 30 & 53,33 & 36,7 & 0,260 & 0,420 & & \\
\hline 18 & $1973 / 2$ & 50 & 92,00 & 92,00 & 0,670 & 0,918 & & \\
\hline 19 & 1974 & 42 & 40,48 & 40,48 & 0,492 & 0,662 & & \\
\hline 20 & 1975 & 28 & 97,30 & 92,86 & 0,746 & 0,858 & & \\
\hline 21 & 1976 & 21 & 100 & 100 & 0,662 & 0,784 & 10,98 & 24 \\
\hline
\end{tabular}


From this material it becomes evident, that only the samples from Cape Town and from its surrounding area (Stellenbosch, Grabouw) can be classified as capensis in the classical sense (with exception perhaps of colony Bredasdorp 1, sample 11; although this colony belongs to a commercial beekeeper, who migrates with his bees through the whole southern part of the Cape Province). No uniformity was found even in the capensis colonies in the area near Cape Town, the frequency of bees with spermatheca varying between 50 and $100 \%$.

Most of the spermathecae there however are large, the size being similar to that of the classical Cape bee as described in earlier papers (Onions 1912, Anderson 1963).

All the other samples (No. 1-14, table 3) differ greatly from the classical picture of the Cape bee. Spermathecae are either missing completely or they are small in the majority of the bees. The frequency of the "capensis spermatheca" (with a lower limit of $0,30 \mathrm{~mm}$ ) exceeds ten percent in the mentioned case of Bredasdorp only. The number of ovarioles is lower than that of the typical capensis though higher than that of the " adansonii " workers.

The bees in the apiaries visited were more or less dark in colour, but in must of the colonies a varying number of yellow banded bees was observed. During a single visit nothing definite can be stated about their agressiveness, but it seems to be less than in the case of "adansonii" bees further north. In some cases (Heidelberg, Bredasdorp) typical mass attacks occured, starting with a clearly perceptible evaporation of the alarm substance isopentylacetate. This was observed even after a weak irritation at the entrance. The gentlest bees were found at Stellenbosch; the colonies there were worked only with modest amount of smoke, without any protective cloths.

\section{4. - DISCUSSION}

The results of this investigation indicate that the area of the "classical" Cape bee is very restricted (distance Cape Town-Grabow $60 \mathrm{~km}$; the region west of Cape Town however was not investigated). How is this peculiar genetic compound maintained in this small area, in spite of the high mobility of colonies of bees?

This is an open question, because the geographical isolation of the Cape bee as supposed by Kerr and P. Araujo (1958) is not existing. In the semidesertic belt of the Karoo and the Kalahari wild colonies of bees occur, and in a restricted way even beekeeping is practiced (a tube hive of the Kalahari is shown at the Apicultural Museum of Kalmthout, Belgium). To be sure the population of bees is scarse in this region because of the limited flowering time and the shortage of nesting sites. 
The central part of the Cape bee area (Cape Town-Stellenbosch-Grabouw) is not at all isolated geographically, at least to the east. There are beekeepers, some of them with many hives, everywhere along the coast-not to mention the high number of wild colonies that exist (the practice of obtaining supplementary colonies by baiting wild swarms with empty boxes was seen on several occasions).

This does not mean, of course, that the situation was the same in the past as it is at present. The Cape Flats (Fig. 3) were flooded several times during the pleistocene by rising sea level thus making the Cape Peninsula an island off the shore of the African continent (GUy 1976). During one of these periods a part of the Southafrican bee population may have evolved separately on the Cape into an island race. This may have subsequently extented within a restricted area on the continent. The European races too evolved in transitory isolation during the cold periods of the pleistocene.

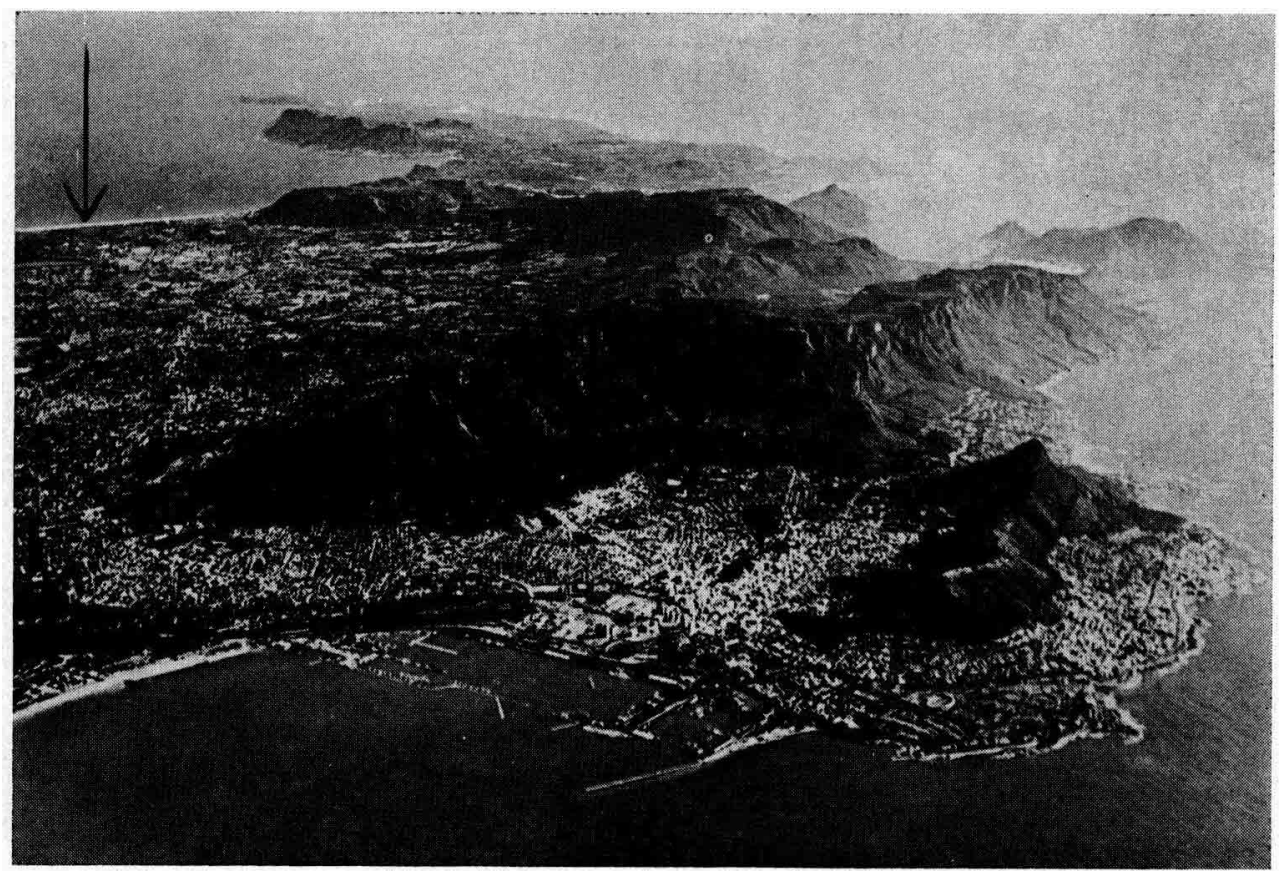

Fig. 3. - The Cape Peninsula (length $-65 \mathrm{~km}$ ). Arrow : Cape Flats.

During our experimental work with capensis another process was discovered which would explain the survival of the pure capensis genotype even in a restricted area and in spite of insufficient isolation and continual importation of other bees. All colonies with original queens from Stellenbosch (except one, no. 21, received 1976) used for experimental work showed a low degree of 
uniformity (table 3) : pigmentation and pilosity were very variable (see the distribution of samples in a multivariate analysis, RutTNer 1976) and the portion of bees with well developed spermatheca was, in part, considerably lower than $100 \%$.

TABLE 4. - Increase of frequency and size of the worker bee spermatheca during several generations of thelytokous parthenogenesis.

\begin{tabular}{|c|c|c|c|c|c|c|}
\hline \multirow{3}{*}{ Thelytokous generation } & \multirow{3}{*}{$\mathbf{n}$} & \multicolumn{5}{|c|}{ Spermatheca } \\
\hline & & \multirow{2}{*}{$\begin{array}{l}\text { Frequency } \\
(\%)\end{array}$} & \multicolumn{4}{|c|}{ diameter (mm) } \\
\hline & & & $\overline{\mathbf{x}}$ & $\mathrm{s}$ & $\max$ & $\min$. \\
\hline 0 (queen No. 19, table 3) & 42 & 40,48 & 0,492 & 3,90 & 0,662 & 0,343 \\
\hline 1 & 4 & 75 & & & & \\
\hline 2 & 12 & 100 & 0,611 & 2,75 & 0,723 & 0,539 \\
\hline 3 & 29 & 93,1 & 0,621 & 4,56 & 0,845 & 0,453 \\
\hline 5 & 40 & 100 & 0,742 & 2,50 & 0,833 & 0,674 \\
\hline 6 & 14 & 100 & 0,786 & 1,78 & 0,858 & 0,747 \\
\hline
\end{tabular}

If a new worker generation is raised parthenogenetically from these bees, a striking change will occur regularly. The yellow coloured bees diminish, the tomenta become scarcer. Simultaneously the percentage of bees with developed spermatheca increases, as well as their diameter. After three to four generations of parthenogenetic reproduction all worker bees show a well developed spermatheca (table 4). Thus a type of less variability appears, exactly corresponding to the classical type of the Cape bee.

The cytogenetic analysis of the parthenogenesis in the Cape bee was just started. The fact that the offspring is different from the parents, the changes being predictable, favours the hypothesis that some kind of automictic reproduction occurs : The reduction of chromosomes is not simply suppressed, but haploid nuclei are formed in the egg which fuse with each other later on thus restituting the diploid phase without fertilization.

Heterozygous loci are expected to become homozygous during this process, which is shown by a segregation of characteristics. In our experiments segregation was observed, not randomly however, but unilateral biased in favour of capensis characteristics. Increase in yellow colour or decrease of frequency of the spermatheca was never observed. This is explained very simply by the biology of the Cape bee : capensis workers start egg laying much earlier than do workers of other races. If a mixed groupe of workers has the chance to develope the ovaries (the inhibition exerted by a queen being 
removed), then those bees will always start egg laying first and inhibit later on the developement of ovaries of other bees, which have the highest portion of capensis genes.

Thus in each thelytokous generation an autoselection occurs directed towards a homozygous capensis genom.

Still another factor will act in the same direction : as already reported by ONIONs (1912) capensis workers will intrude into other colonies and start egg laying after the queen has vanished. This event was observed rather frequently in the experiments we conducted as soon as capensis colonies were placed near colonies of other races. This is another way to increase the frequency of capensis genes.

Thelytokous parthenogenesis has a positive selective value only if queenless colonies succeed to raise fertile queens from worker produced female larvae. Otherwise the queenless colonies will dwindle in spite of the limited production of worker bees and die in the next winter at the latest.

Onions (1912) did observe this event of "selfsaving" of a queenless colony three times only. In our experiments we saw this more frequently; the data collected seem to indicate that spontaneous queen raising in thelytokous colonies succeeds more frequently in the first half of summer as after midsummer. These colonies loose much of their strenght shortly after removal of the queen (rejecting behaviour; Anderson 1965), but they recover very quickly as soon as a young queen heads the colony.

The same was reported by beekeepers in the Cape area. The "rescue" of queenless colonies by laying workers seems to be a rather frequent occurence. It was reported repeatedly that loss of colonies due to the loss of the queen does not occur, queenless colonies always raise a young queen after a time. Thus thelytokous reproduction may be of selective value to the population.

Other factors of superiority of the Cape bee in its territory depend rather on its better ecological adaptation and not on its capacity to thelytokous reproduction.

The south point of Africa is termed Winter Rainfall Area, resembling closely the Mediterranean type of climate : cool, rainy winter and dry summer. This is in strong contrast to all other regions of Africa south of the Sahara. Round the Cape of Good Hope this climate is most strongly marked (fig. 2); this region where the typical Cape bee is found, belongs to the humid, resp. subhumid zone of the Winter Rainfall Area (Poynton 1971).

For the bees the climatic conditions during winter are doubtless the most crucial ones. On the Cape it is true that temperatures below the freezing point occur only at higher altitudes, as a result of the oceanic influences. As 
shown in table 5, the mean winter temperature in Cape Town and in Beaufort West (on the edge of the Great Karoo, $450 \mathrm{~km} \mathrm{NW}$ of Cape Town, altitude $870 \mathrm{~m}$ ) are very similar, only with stronger extremes in Beaufort West. Cape Town however has much more rain, less sunshine and a higher relative humidity during the winter. The area of the "typical "Cape bee corresponds in a striking way with the most humid zone of the Winter Rainfall Area.

The closest relatives of the Cape bee, the bees of the scutellata-adansonii groupe, live mostly in the African savanna. They are adapted to tolerate low temperatures (even below the freezing point) for a short time, but not long periods of high humidity without flight. This was also shown during the spread of African bees in South America. As the beekeepers of Cape Town state, "adansonii" bees imported to the region disappear within one or two years. Only the Cape bee can be maintained on long term. I was told that during the winter hive boxes are wet inside because of the high humidity. We understood that colonies from the north could not endure these conditions.

Most of the wild colonies of capensis live in the mountains. Thus it is of interest to compare the data of the duration of sunshine of places of higher altitude as the Table Mountain (table 4). The difference is still more striking there.

TaBle 5. - Data on the climate of Cape Town (Winter Rainfall Area) and of Beaufort West, Summer Rainfall Area, semi-arid zone (from Climate of South Africa, part 8. Weather Bureau, Pretoria 1974).

\begin{tabular}{|c|c|c|c|c|c|c|}
\hline & & May & June & July & Aug. & Sept. \\
\hline Mean temperature & $\begin{array}{l}\text { Cape Town } \\
\text { Beaufort West }\end{array}$ & $\begin{array}{l}15 \\
14\end{array}$ & $\begin{array}{l}13 \\
12\end{array}$ & $\begin{array}{l}12 \\
11\end{array}$ & $\begin{array}{l}13 \\
13\end{array}$ & $\begin{array}{l}14 \\
15\end{array}$ \\
\hline Mean of minimum temperature & $\begin{array}{l}\text { Cape Town } \\
\text { Beaufort West }\end{array}$ & $\begin{array}{r}11 \\
8\end{array}$ & $\begin{array}{l}9 \\
5\end{array}$ & $\begin{array}{l}8 \\
5\end{array}$ & $\begin{array}{l}9 \\
6\end{array}$ & $\begin{array}{r}12 \\
8\end{array}$ \\
\hline Mean of meximum temp. & $\begin{array}{l}\text { Cape Town } \\
\text { Beaufort West }\end{array}$ & $\begin{array}{l}19 \\
21\end{array}$ & $\begin{array}{l}18 \\
19\end{array}$ & $\begin{array}{l}17 \\
18\end{array}$ & $\begin{array}{l}18 \\
20\end{array}$ & $\begin{array}{l}19 \\
23\end{array}$ \\
\hline Precipitation (mm) & $\begin{array}{l}\text { Cape Town } \\
\text { Beaufort West }\end{array}$ & $\begin{array}{l}87 \\
13\end{array}$ & $\begin{array}{r}107 \\
7\end{array}$ & $\begin{array}{r}94 \\
8\end{array}$ & $\begin{array}{r}82 \\
9\end{array}$ & $\begin{array}{l}59 \\
14\end{array}$ \\
\hline Rel. humidity of the air & $\begin{array}{l}\text { Cape Town } \\
\text { Beaufort West }\end{array}$ & $\begin{array}{l}65 \\
34\end{array}$ & $\begin{array}{l}64 \\
33\end{array}$ & $\begin{array}{l}67 \\
35\end{array}$ & $\begin{array}{l}64 \\
31\end{array}$ & $\begin{array}{l}61 \\
29\end{array}$ \\
\hline $\begin{array}{l}\text { Mean duration of sunshine ( } \% \text { of } \\
\text { possible) }\end{array}$ & $\begin{array}{l}\text { Cape Town } \\
\text { Table Mountain } \\
\text { (alt. 76I m) } \\
\text { Beaufort West }\end{array}$ & $\begin{array}{l}32 \\
76\end{array}$ & $\begin{array}{l}42 \\
78\end{array}$ & $\begin{array}{l}49 \\
80\end{array}$ & $\begin{array}{l}41 \\
79\end{array}$ & $\begin{array}{l}47 \\
74\end{array}$ \\
\hline
\end{tabular}


Thus the Cape bee evolved in ecological isolation, as an adaptation of an originally tropical bee to the conditions of a temporate climatic zone with humid winter. This zone extended substantially farther to the north during the pleistocene, compared with today (M.J. WeLLS).

As we have to assume that $A$. mellifera is of tropical origin as the other species of the genus, it must be concluded that mellifera races with the ability to live in the temperate zone differentiate as well in southern direction as to the north on the African continent. Evidence for the astonishing adaptability of this species! This adaptation of course is less advanced in the south as in the north; it has to be considered that Cape Town is situated $34^{\circ}$ south, while south Scandinavia which is the northern limit of the autochthonous distribution of A.m. mellifera, is situated at $60^{\circ}$ north (the West European bee A.m. mellifera evolved from A.m. intermissa of North Africa). Capensis is not able to overwinter by itself in Central Europe, even in relatively mild places, as shown by our own experience during five years.

Another factor still exists causing difficulties in overwintering besides the duration of the cold periode without flight (three to four months) : The lack of flight inhibition by low temperature, independently from intensity of radiation. The not adapted bees start to fly on bright sunny winter days in spite of low temperature, all flight bees are consequently lost in a short time. The same has been observed in other races of southern origin, e.g. in A.m. lamarckii from Egypt.

The exact size of the central area of distribution of A.m. capensis is not yet fully determined; little is known about the bees from the region north and north west of Cape Town. At any rate the area of distribution is by far smaller than it has been assumed so far. Only a rough estimation is possible about the size of the capensis population. On the Cape Peninsula about 1000 colonies are owned by beekeepers (personal communication by Mr. BIRCH, Chairman of the local Beekeepers Ass.), besides a not insignificant wild population. In the region Stellenbosch-Strand-Grabouw (Elgin) quite a number of important bee yards are found and wild colonies occur everywhere. An estimated 10000 colonies of bees does not seem to be unrealistic for this region. Even if it should be proved in future that the same number of colonies of capensis has to be assumed for the humid zone of the Winter Rainfall Area north of Cape Town (fig. 2) this is a very small population size of a distinct race of an insect.

Today this population is in danger to some extend by beekeeping activities. Many beekeepers believe that "adansonii" colonies become stronger and yield more honey. It is not difficult to escape wintering problems in the Cape region by practising migratory beekeeping. Many colonies of northern 
(not capensis) origin are kept in the region (in former years even European races were recommended, namely Italians, but they did not survive).

The Cape bee, on the other hand, has a number of valuable features important also from an economic point of view. The ecologic adaptation has been mentioned before. Because of their gentle temperament the capensis colonies are easy to handle, and swarming tendency is low. Thus it is an ideal pollinator of crops; at a big fruit farm at Elgin (Grabouw) for instance 600 capensis colonies are kept for pollination purposes only.

For all these reasons a sanctuary for the Cape bee should be established. The well isolated Cape Peninsula, the very center of this bee, is excellently suited for this.

How is the relatively dark bee east of Grabouw however to be classified? In all cases were a clear geographic isolation (by sea, deserts or high mountains) is missing, the bee races show gradual transitions instead of sharp boundaries. A good example is the slow transition from the northern "forest bee "(A.m. mellifera) to the southern "steppe bee" (A.m. carnica) in Western Russia (Alpatow 1933; see GeEtze 1964). A similar gradient is found on the southern point of Africa, between Cape Town and Knysna : Decrease of size and frequency of the spermatheca as well the number of ovarioles of worker bees, and increase of yellow pigmentation.

This gradient is maintained in spite of the intensive migration with colonies of bees-a clear proof of a still existing selection pressure in favour of the Capensis genom in the south. It is of interest to learn whether thelytokous reproduction occurs in this belt round the area of the typical capensis. During the present work there was no occasion to study this question.

Reçu pour publication en mai 1977. Eingegangen im Mai 1977.

\section{ACKNOWLEDGMENTS}

I wish to acknowledge with gratitude the valuable assistance I received while this research was in progress from my colleagues, of the Plant Protection Research Institute, Dr. R. H. Anderson and David Fletcher; Peter Mountain, Chairman of the SA Beekeepers Association; Major General G. D. Moodie, Honey Wood Farm.

\section{RÉSUMÉ}

LE PRoblème de L'ABeille du CAP (Apis mellifera capensis eschöltz) : PARthénogénèse, TaIlle de LA POPUlation, Évolution

L'abeille du Cap, de la péninsule du sud de l'Afrique, est une particularité biologique fort discutée, dans la mesure où chez elle des cufs non fécondés pondus par des ouvrières donnent naissance à des femelles diploïdes, et non à des mâles. Les ouvrières pondeuses de cette race produisent la substance royale comme une véritable reine et il se forme une cour autour d'elles. Les ouvrières capensis sont, par leur constitution, beaucoup plus proches des reines que des ouvrières des autres races : le nombre d'ovarioles est supérieur de 15-25 et il existe une spermathèque d'un diamètre de $0,3-0,8 \mathrm{~mm}$ (fig. 1). 
Selon les anciennes données l'aire de répartition de cette race comprenait toute la péninsule du Sud de l'Afrique; elle était limitée au nord par la ceinture des déserts du Grand Karoo et du Kalahari, dépourvus d'abeilles. Une étude plus précise a maintenant montré qu'il n'existait pas actuellement d'isolement géographique par une région sans abeilles et que l'aire de l'abeille capensis typique, possédant les caractéristiques décrites ci-dessus, était restreinte à la moitié de la presqu'île du Cap et à son voisinage immédiat (fig. 2). Puisque la péninsule du Cap a été totalement isolée du continent à plusieurs périodes du Pléistocène en raison de l'élévation du niveau des mers, il est possible qu'il s'agisse d'une race insulaire à l'origine.

Du point de vue biométrique il est incontestable que l'abeille capensis avec les caractéristiques habituelles ne se rencontre pas plus au nord (groupe scutellata-adansonii). Les caractéristiques indiquées (pigmentation foncée du corps, plus grand nombre de poils sur l'aile antérieure) ne fournissent aucun caractère distinctif fiable (tabl. 1). Il existe une large zone de passage à l'abeille africaine jaune dans laquelle les caractères propres à l'abeille du Cap ne sont présents qu'accessoirement (tabl. 2,3).

Dans la zone centrale même de l'abeille capensis la population d'abeilles est très peu homogène même en ce qui concerne les caractères propres à l'abeille du Cap (tabl. 3 échantillons 15-21).

Dans la reproduction par parthénogenèse il se produit une dispersion accrue de génération en génération du type homogène capensis. Ce phénomène est probablement la conséquence d'une recombinaison par la fusion de deux noyaux haploïdes en dehors de la méiose (done d'une automixie), en relation avec une sélection spontanée des types capensis bien marqués (qui commencent à pondre plus tôt que les autres). Dans une population hybride ce processus conduit donc en permanence à la restitution d'un génome capensis homozygote.

Des colonies avec des ouvrières capensis pondeuses peuvent même après un orphelinage prolongé élever des reines à partir de larves nées parthénogénétiquement et réformer ainsi une colonie avec reine. Ce type de reproduction peut présenter un avantage du point de vue de l'évolution.

A cause de la taille réduite de sa population (10 000 à 20000 colonies) l'abeille du Cap est aujourd'hui menacée dans son existence par les méthodes modernes d'apiculture (transhumance, importation d'autres races). Il est recommandé de créer une réserve capensis sur la presqu'ile du Cap.

\section{ZUSAMMENFASSUNG}

\section{DAS PROBlem der KaPBiene (Apis mellifera capensis escholtz) PARTHENOGENESIS - POPULATIONSGRÖSSE - EVOLUTION}

Die Kapbiene von der Südspitze Afrikas ist eine vieldiskutierte biologische Besonderheit insoferne, als bei ihr aus unbefruchteten Eiern von legenden Arbeiterinnen diploide weibliche Tiere (und nicht Drohnen) entstehen. Die legenden Arbeiterinnen dieser Rasse geben wie eine richtige Königin queen substance ab und es wird rund um sie ein Hofstaat gebildet. Schon in ihrer Anlage sind Kap-Arbeiterinnen Königin-ähnlicher als die Arbeiterinnen anderer Rassen : Die Zahl der Ovariolen ist auf 15-25 erhöht und es ist eine Samenblase von 0,3-0,8 mm Durchmesser vorhanden (Abb. 1).

Nach früheren Angaben sollte das Verbreitungsgebiet dieser Rasse die ganze Südspitze Afrikas umfassen, nach Norden isoliert durch den bienenfreien Wüstengürtel der Great Karoo und der Kalahari. Eine genauere Untersuchung hat jetzt ergeben, daß eine geographische Isolierung durch ein bienenfreies Gebiet derzeit nicht existiert und daß das Areal der typischen Kapbiene, mit den oben beschriebenen Merkmalen, nur auf die Kaphalbinsel und eine unmittelbar anschließende Zone beschränkt ist (Abb. 2). Da die Kaphalbinsel in mehreren Perioden 
des Pleistozäns durch Ansteigen des Meeresspiegels vollkommen vom Festland isoliert war, handelt es sich möglicherweise ursprünglich um eine Inselrasse.

Biometrisch ist die Capensis mit den üblichen Merkmalen von den Bienen weiter nördlich (scutellata-adansonii-Gruppe) nicht einwandfrei zu trennen. Die angegebenen Charakteristika (dunkle Körperfarbe, erhöhte Borstenzahl auf den Vorderflügeln) ergeben kein verläßliches Unterscheidungsmerkmal (Tab. 1). Es existiert eine breite Übergangszone zur gelben afrikanischen Biene, in der die typischen Kap-Merkmale nur angedeutet vorhanden sind (Tab. 2,3).

Die Kapregion unterscheidet sich vom Savannen- und Halbwüstengebiet des übrigen Südafrika durch ein im Winter feuchtes und kühles Klima, an das die Kapbiene gut angepaßt ist (ökologische Isolierung). In Afrika haben sich also sowohl im Norden wie im Süden aus tropischen Rassen Typen mit Anpassungen an die Klimabedingungen der gemäßigten Zone entwickelt.

Auch im Kerngebiet der Capensis ist die Bienenpopulation sehr wenig einheitlich, selbst in den typischen Kapmerkmalen (Tab. 3, Proben 15-21). Bei parthenogenetischer Fortpflanzung kommt es jedoch zu einer von Generation zu Generation verstärkten Herausspaltung eines homogenen Capensis-Typs. Diese Erscheinung ist vermutlich die Folge einer Rekombination durch Verschmelzung von zwei haploiden Kernen aus der Meiose (also einer Automixis), in Verbindung mit einer selbsttätigen Selektion der ausgeprägtesten Capensis-Typen (die früher als die anderen mit der Eiablage beginnen). Dieser Prozess führt in einer Mischpopulation permanent zu einer Restitution homozygoter Capensis-Genome.

Völker mit legenden Kap-Arbeiterinnen können selbst nach längerer Weisellosigkeit aus parthenogenetisch entstandenen Larven Königinnen aufziehen und in der Folge zum weiselrichtigen Zustand zurückkehren. Damit kann diese Art der Fortpflanzung einen evolutiven Vorteil bedeuten.

Wegen der Kleinheit der Population (10 000-20 000 Völker) ist die Kapbiene heute durch die Methoden moderner Bienenwirtschaft in ihrer Existenz bedroht (Wanderung, Import anderer Rassen). Die Errichtung eines Capensis-Reservates auf der Kaphalbinsel wird empfohlen.

\section{REFERENCES}

Anderson R. H., 1963. - The laying worker in the Cape honeybee, Apis mellifera capensis. J. Apic. Res., 2, 85-92.

Anderson R. H., 1976. - Some aspects of Cape bee biology. Apimondia Symposium Pretoria (in print).

Birci. - (Personnal communication).

Dupraw E. J., 1965. - The recognition and handling of honeybee specimens in non-Linnean taxonomy. J. Apic. Res. 4 (2), 71-84.

Goetze G., 1964. - Die Honigbiene in natürlicher und künstlicher Zuchtauslese. P. Parey, Hamburg.

Guy R. D., 1976. - Whence the Cape bee? South African Bee J., 48 (3), 9-11.

JACK R. W., 1916. - Parthenogenesis amongst the workers of the Cape honeybee : Mr. G. W. Onions experiments. Trans. Ent. Soc. London, 396-403.

Kerr W. E., V. Portugal-Araujo, 1958. - Raças de abelhas de Africa. Garcia de Orta, 6, 53-59.

Onions G. W., 1912. - South African « Fertile-Worker Bees ». Agric. J. Un. S. Afr., 3, 720-728.

Poynton R. J., 1971. - Characteristics and uses of trees and shrubs. Forest Department Pretoria, Bulletin no 39.

Ruttner F., 1976. - The races of bees of Africa. Proceedings 25. Intern. Beekeeping Congr., 344-364. Bucarest 1976.

Ruttner F., Koeniger N., Veith H. J., 1976. - Queen substance bei eierlegenden Arbeiterinnen der Honigbiene, Apis mellifica L. Naturwissenschaften, 63, 434.

Welts M. J. - (Personnal communication).

WOYKE J., 1976. - The density of the bristles covering the wing as discrimination value between African and other races of bees. Apimondia Symposium Pretoria (in print). 